JRAI 8 (1) 2002

\title{
City of details: interpreting the personality of London
}

\author{
ADAM REED \\ University of Surrey
}

This article investigates the ways in which a group of enthusiasts for London constitute their city. The 'personality' attributed to London is described as well as the interpretive acts that reveal it. These people, who also lead walking tours across the city, privilege 'detail' as their term of analysis. The article examines the identified qualities of that category, in particular its perceived capacity to animate the plural time-spaces of the city. This sensitivity to detail is presented as part of a sensing of place, which allows people to regard themselves as uniquely able to see the city. The article is intended as a contribution to the ethnography of London.

\section{Introduction}

London is not just a place; it is also a kind of being. It is growing, declining and decaying like a body. It gets things wrong a bit and gets sick. And then things happen to it, you know like the bombing in Soho. ${ }^{1}$ It really does seem to have a life of its own. Not just lively, the things going on that people do, but I mean it does seem to have a sort of existence as a being. 
This essay is about a particular vision of London, put forward and developed by a set of people who claimed to be long-time enthusiasts for the city. It is about the kind of attributes they assigned to London and the terms of description that for them revealed it. That vision, like many others, past and present (cf. Eade 2000, Sennett 1994), relied on a reification of the city as person. London, I was frequently told, was not just a 'place', a location where people dwelt or passed through, but a 'being' that acted independently and was acted upon (the quote above was typical of these pronouncements). The city was said to have its own 'life' and 'body', linked to, but separate from, the lives and bodies of its residents and visitors. One of the stated aims of these enthusiasts was to understand what they regarded as the personality or character of London.

The men and women I talked with all declared a lifelong passion for the city. That interest had led each of them, independently, to take up professional guiding - to lead walking tours through the city. Indeed, it was through this activity that I first met them. As self-employed guides they worked for a number of different walking tour companies which co-ordinated bookings and advertising in return for a commission payment. They presented this work as a way of subsidising their private explorations of the city, an occupation preferable to the tedium of office work and salaried careers (most only started guiding when middle aged). Although leading walking tours forced them to communicate an image of the city to tourists, they regarded this activity as peripheral, a distraction from their very personal engagements with the metropolis. Guiding was something they did precisely because they were enthusiasts; first and foremost they defined themselves as lovers of London. While this essay is about a vision of the city put forward by people who happen to guide, it is not about the activity of tourism. At times during this essay I 
will introduce the literature on tourism in order to mark the difference between the vision that is my subject — those of these lovers of London — and that produced as a consequence of the 'tourist gaze' (Urry 1990, 1995). Guiding, however, did encourage my subjects to reflect upon the reception of their vision, to articulate its distinctiveness and resistance to public consumption.

These enthusiasts, who I bring together as a single set of ethnographic subjects, led quite separate lives. Some of them knew each other through guiding, but generally contact between them was minimal. After meeting individuals on walking tours, I interviewed each of them privately and sometimes accompanied them on their solitary explorations of the city. Although they identified themselves as Londoners, whether by birth or by migration from within the United Kingdom, this was not a bond that drew them together. In fact, individuals frequently told me that by disposition they were 'loners'. Yet, while not often in what anthropologists would conventionally recognise as durable relationships, they appeared to exist together in terms of their expressed relationship to the city. To me, they appeared as a single 'interpretive community' (Fish 1980), bound by the terms of analysis or interpretive acts that allowed each of them to experience a vision of London. ${ }^{2}$ Their city-seeing-eyes saw evidence of the character of the metropolis everywhere. I am concerned with the capacities and qualities of action of their favoured term of description and with the kind of city that strategy seemed to constitute for them. Not just a vision of London, but a specific visionary subject appeared to emerge as a consequence of this shared interpretive activity.

My inquiry takes something from the investigations carried out by Strathern (1988, 1991, 1992, 1995), particularly her lessons on the action / work of what appear 
straightforward terms of description (cf. Riles 2000). Strathern focuses on the agency of a typical anthropological category — the 'relation'. She demonstrates both of its sides: the capacity to join or connect as well as the capacity to maintain itself as contexts shift. Those actions are exhibited through ethnographic projection, seen to be performed by either Melanesian or English subjects. ${ }^{3}$ Strathern points out that ethnography is already loaded down with assumptions about the work of the relation; in whichever capacity, it is regarded as something that subjects own or see. The problem she therefore faces is how to make anthropologists realise that the relation is also at work within their texts, busy providing effects of meaning. In both their guiding and private inquiries about London, the people I worked with claim to pay attention to a different term of description'detail'. By contrast to the category of the relation, the action of detail is long acknowledged as a textual strategy, part of the aesthetic equipment for scholarly and literary acts of communication (cf. Lukács 1981). However, unlike the relation, detail is not usually regarded as the indigenous category of ethnographic subjects, nor is it presented as the motivation for social action. It is visible only as part of the form of ethnography - a feature of text. One of my challenges therefore is to make detail also appear the content of ethnography, an interpretive activity that is embraced when people look with city-seeing-eyes.

This essay is also about a 'sensing of place' (Basso 1996), the manner in which a set of persons animate a city and imagined that the city animates them. Basso claims that relationships to places are mostly richly lived and felt when persons make them the object of awareness and reflection (54). Among those I met London was the focus of abiding interest, of self-conscious attention and strong sentiment. They told me that 'detail' was 
not an abstract category, but rather a quality of the city itself, whose design could be found in the landscape around us. This interpretive activity was always place-centred; in paying attention to detail, these people were pausing to sense the city. While they never acknowledged that their analysis constituted their vision of London, they did draw pleasure from the feeling that London made or animated them. Indeed, they believed that the category of place could not sufficiently describe their relationship to the city; it denied their sense of London as a personality (\& being). In considering their 'lived topography' (58), therefore, one has to include a rejection of what place meant to them.

Eade (2000: 4) points out that reifying London as a person remains a powerful analytical (\& ideological) move. Speaking about a city as though it has a distinctive identity or essential characteristics is commonplace, in both scholarly and popular commentaries. In fact Eade admits that in the end he himself found it impossible to avoid discussing London in those terms, as though it existed as an entity in its own right (179). In this essay I am not concerned to produce my own theory of the city, but rather to present someone else's vision and map out its dimensions. Unlike many scholars, who are concerned to identify abstract types of cities, for the subjects of my fieldwork precisely which city they were talking about was of vital importance. They offered me a theory of London. Indeed, I believe that an anthropological contribution to the study of cities might distinguish itself on this basis, by first paying attention to the different kinds of city that subjects constitute themselves (and the terms of description or analysis they draw upon). Instead of continuing to favour accounts of processes within the city, such a project would attend to descriptions of the city (Low 1996: 384; cf. Eade 2000). In 
outlining this particular vision, just one of many competing representations of the city, I also begin to provide some ethnography (or 'theories') of London.

\section{City of details}

'It's as if I'm in a dream', Sally told me. We sat together in a pub just off the Strand at the end of her guided walk, advertised as following 'In the Footsteps of Sherlock Holmes'. But here she spoke of a private enthusiasm, her fascination with the River Fleet, an ancient waterway now buried beneath the modern city. 'I'm well aware', she went on, 'that as I walk around London I'm in a dream, imagining it as it was. If I walk down Farringdon Road, which is the dreariest road imaginable, I'm not looking at what's there now, I'm looking, you know, at what it was like before'. Sally started conducting walking tours in her late forties after being offered a redundancy package from the company that employed her as a legal secretary. But her interest in the Fleet was of much longer standing. She described returning again and again to Farringdon Road, where the widest stretch of that river was covered over in the nineteenth century. When standing on the pavement beside what is now a busy traffic artery on the western edge of the old City (now the financial district of London), Sally claimed that she was able to forget the ugly office buildings, the noise and fumes emitted by passing automobiles. For once she started walking that scene was transformed, revealing shifting visions from the past lives of the river.

Sally told me that she sometimes saw the water of the Fleet running fast and clean; ahead, beyond the stone walls of the City, she saw open pasture and distant hillocks. Windmills dotted this landscape and hawks circled the air. At other times the 
river was dark and filthy, cast in shadows by a canyon of tenements that overhung the banks and led down to its mouth at the Thames. Sally remembered seeing coarse cloaked women emptying their slop buckets into the water, butchers with greasy leather aprons hacking at cow carcasses and allowing the discarded entrails to float away, or coal barges with their sails down losing their load overboard as they tried to navigate a narrow course. Sometimes the river appeared completely dried up, buried under rubbish and built over with tumbledown yards and alleys of slum dwellings. Down there, she said, everything was pitched in darkness, but the sky was hazy and bright, a reflection of the gas lit world of respectable streets on the ground above. And then with a start Sally would find herself back in Farringdon Road, once again confronted with the roar of modern traffic.

The River Fleet is no longer marked on London maps, but Sally claimed that she could still see it. Indeed, she had travelled the full course of the river many times, following it from the hills of Hampstead and Highgate, down through Kentish Town and Camden, St Pancras and into Clerkenwell, Holborn and Blackfriars, where it meets the Thames. On these expeditions, she asserted, the river appeared to her in all its past guises. At one moment it was a medieval stream running out into the countryside, then a seventeenth century open sewer and next a Victorian ditch, partly covered over and lined on either side by the rookeries of the poor and villainous. She told me that the Fleet could still leave its mark, that on occasions the basement of homes in Hampstead and Blackfriars were flooded, engulfed by what might seem tide water from the past.

Like the other enthusiasts for London I met, Sally claimed to be able to perceive the pasts of the city in the present. I was told that this ability was a solitary gift, not easily 
communicated to others. On walking tours, for instance, she reported that customers often failed to share her vision.

Sometimes you get somebody, who says, 'I can't see that. Where is medieval London?' You know, 'You've not shown me anything'. And then I realise that a lot of it is in my head. I can see things mentally, which have gone. You explain it to people and some of them can do it, but not everybody does. They can't seem to imagine how it has changed.

Not just tourists, but other residents of London were said to be unable to see what she and other enthusiasts could. As visionaries, they drew a contrast between themselves and the rest of the city's population. Rather than treating London as a place that had to be passed through, in order to get back and forth to work or travel from A to B, they saw it as something to enter or commune with. ${ }^{4}$ These men and women believed that other residents were blind to the city that they knew and loved. To them, it was these people's imagination (and not their own) that seemed enchanted. ${ }^{5}$

Several of those I interviewed cited the house of expatriate American artist Dennis Severs as their inspiration for engaging with London. ${ }^{6}$ Located in the Spitalfields district of the East End, this eighteenth century terraced brick building had been transformed by the owner-artist into a work of conceptual art. When I visited the house it was decorated in what one took to be period styles, but with extravagant baroque flair: bird cages, mountains of blue and white china, carefully displayed assemblages of vegetables and 
fruit. The 'game', so I was told, was to imagine that a Huguenot family of silk weavers had just stepped out. Everywhere clues were provided of their sudden removal. In the rooms one came across ruffled bed sheets, sliced open halves of grapefruit, the remains of breakfast on a morning table, used bed pans, recently snuffled candles, toys left on the stairs. A leaflet explained that the artist's work came out of the visitor's own experience, that 'What you imagine... is his art'. Throughout the house little cards were displayed, reminding one not to treat the objects on view as antiques or period pieces. The significance of these items was said to lie in the relation between them, in the stories, feelings and memories that their alignment might evoke. One hand written note was found throughout the house, the slogan, 'You either see it or you don't'.

Enthusiasts told me that they took the particular way of seeing that they had learned at Severs' house and applied it to London. Thus, they imagined a backward looking city, more in tune with its origins and pasts than its present, outward manifestation. The objects of that city (like those found in Severs' house) were treated as fragments, evidence of what was now passed or missing from view. To them, London appeared to be still full of clues, as if the actors of past events had only just left the scene. By paying close attention to these objects, and the relations between them, they believed they might gain access to the pasts of the city, its memories and stories. So a faded Second World War air raid shelter sign, pointed out on a passing wall, was the spark for a vision of London during the Blitz. The fanlights and link-snuffers (small ironwork cones placed on either side of the front door used to extinguish torch light) in a row of eighteenth century terraced houses were the cue for stories told about the hazards of night travel in the city before artificial lighting. And a dormer window within a tiled roof, at the 
top of what looked like a very ordinary post-war pub, was the prompt for a vision of medieval London street life. On walking tours attention was drawn to the discoveries made when the ground was dug up or buildings stripped away. Whether an old Roman stone found under a car park, a medieval well located in the cellars of a glass office building or a petrified cherry tree found behind shelves in the walls of a pub; to them London seemed to be in a state of perpetual recall. It was as though these objects spoke and were able to store and release images and sounds from earlier times.

The pasts of London, I was told, could also be accessed through the scrutiny of city names. Not just the individual titles of streets and districts, but also those of pubs and landmarks (unlike other European cities, which experienced frequent name changes through invasion, revolution or coup, London's names have remained relatively unaltered). Sally, for instance, told me that she could plot the course of the River Fleet simply by looking out for the clues in street names. Thus, Turnmill Street marked the site on the river where water mills once stood, and names such as Old Seacoal Lane or Stonecutter Street assured her that she was on the right track. She showed how the name of the district Holborn, through which Farringdon Road ran, could be taken apart to reveal another reference to the hidden river ('hol' means ditch or valley and 'born' means burn or river). It was this evidence, she told me, which allowed her to summon the Fleet, 'to see it, to walk it, to feel it'.

The people I met glossed this way of seeing objects (including names) by the claim that they were simply 'paying attention to detail'. They treated this category not just as a term of description, but as an observable feature of London's physical landscape. Indeed, detail was said to be everywhere, if only one learned to see it. At the centre of 
their interpretive activity lay the assumption that detail possessed agency, that this category was in fact a subject. They believed that it drew action from them. Detail, I was told, required its observers to develop a heightened sense of perception; people must hunt down, grasp and attune themselves to the objects of the city. They said that their ability to see past scenes in the present was based on the category's quality of partiality. ${ }^{7}$ Every identified detail was a fully observable object, whose size and physical presence allowed it to be pointed out. It was treated as a relic, emitting the same aura of authenticity and survival as objects found on display in museums and monuments (cf. Horne 1984). Yet this sense of visible immediacy was countered by the knowledge that the object was also part of something missing from view, no longer open to public gaze. As both whole and part, detail appeared to them to exist in plural time-spaces; it was believed to have the crucial capacity to rouse its previous contexts. In this sense, these objects were not 'heritage' pieces - instead of treating detail as evidence of a past that was complete and disconnected from the present (cf. de Certeau \& Giard 1998, Walsh 1992), they valued it as a device to collapse that distance. Indeed, these enthusiasts for London thought themselves living in a city of disassociated objects, which were more significant for the pasts they held within them than for the links that joined them together in the present. It was believed that within every detail an enormous expansion of the city was condensed.

Unlike other European cities, I was told that London's antiquity was rarely open to view. ${ }^{8}$ On guided tours, customers often expressed disappointment at the city skyline. But this non-visibility was precisely what excited the enthusiasm of the people I knew (Sally, for instance, was absorbed by the River Fleet not just because it couldn't be seen, but because it had not even lasted long enough to be photographed). They were 
impressed by the city's hidden biography, by what happened it to over the yearssackings, floods, fires, plagues and bombings — and by what they imagined lay behind or underneath the modern façade. They reported visions not just of buried rivers, but of lost palaces, citadels and monasteries, of plague pits, jousting fields, now cleared slum quarters, places of execution and places of popular entertainment such as bear-baiting or cock-fighting. The objects that provided the clues or entry-points to these pasts were small and discrete. They usually lacked the collection of signs found and consumed around monumental tourist sights (cf. Culler 1988). Indeed, the men and women I knew were generally suspicious of popular attractions such as Buckingham Palace, Trafalgar Square, St Paul's Cathedral or the Tower of London, what they disparagingly termed the 'big stuff'. For while their gaze, like that of visitors to monumental sights, was directed upon objects, this act of looking was not the endpoint of their experience. Unlike the gaze of tourists (cf. Horne 1984, MacCannell 1976, Urry 1990, 1995), the visions they sought could not be objectified by a look or captured as an image on camera and mechanically reproduced. Rather than separating the observer from objects in order to gaze upon them, the attention to detail was meant to draw observer and objects into proximity. Like an act of caress, this look was treated as the first step in soliciting a relationship to the city; I was told that ultimately London could only be grasped through the imagination.

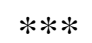

At the top of Dennis Severs' house, a shift in performance occurred. While the floors below were presented as a kind of historical tableau - the movement of a Huguenot silk 
weaving family through time, each room evoking a different stage of their past—when one reached the attic, the evocation became explicitly fictional. Visitors were told that they were now faced with a tableau of scenes from the novels of Dickens. In this room, with its distressed walls and torn ceiling, cobwebs, old four poster bed, stained and ragged sheets, work bench, fireplace and tiny wooden crutch lent against a stool, there was an air of fiction as historical reality (or historical reality as fiction). Severs seemed to invite his audience to realise that these stories could have as much presence for them as the pasts retold on the floors below.

The people I met read voraciously in order to further their knowledge of London. As well as historical accounts of the city, they relied heavily upon its literary representations. These men and women made a point of not depending upon guidebooks. Indeed, they believed that the personality of London was infused with the literature it inspired; reading novels was said to be one of the best ways of bringing the city to life. Many of their guided walks promised customers access to these literary topographies; not just the ubiquitous tour of 'Sherlock Holmes' London', 'Charles Dickens' London' or 'Shakespeare's London', but also that of 'Old Bloomsbury', 'The London of Oscar Wilde’, ‘George Bernard Shaw’s London', ‘Old Literary London' and 'Jane Austen’s London', to name but a few advertised titles. As visionaries that claimed to witness the pasts and fictions of London, they expected that customers would want to be shown the city they had read about.

One man told me that on his tour through Clerkenwell he was often asked for directions to literary landmarks. In particular, customers requested to be shown a house described in a novel by Peter Ackroyd. 
It was only then, when I stopped and looked up from the mangled remains of the ragwort, that I noticed the strangeness of this house. I had assumed at first glance that it belonged to the nineteenth century, but I could see now that it was not of any one period. The door and fanlight seemed to be of the mid eighteenth century, but the yellow brickwork and robust mouldings on the third story were definitely Victorian; the house became younger as it grew higher, in fact, and must have been rebuilt or restored in several different periods. But its most peculiar aspect was its ground floor: it ranged beyond the area of the other storeys and, as I walked closer, I realised that the basement covered the same more extensive ground. These parts of the house were not faced with brick; the walls seemed to be fashioned out of massive stone, and suggested a date even earlier than the eighteenth-century door. A much larger house must once have existed here, of which the ground floor and the basement were the only visible remnants; later additions were on a more modest scale, so that now the central section rose up like some broad tower from its rambling origins (Ackroyd 1994: 2-3).

Although this building is minutely outlined in the novel, the man told me that he had never been able to find it. 'I've looked and looked and looked for it', he asserted, 'but I say it isn't there'. In the end, he concluded that the author had invented the house or else moved it from another setting. His confusion was exacerbated by the fact that he could usually rely on London novels to provide him with specific and accurate topographical directions for the scenes and events portrayed. ${ }^{9}$ Whether following in the footsteps of Sherlock Holmes or a character described by Dickens, he, like other enthusiasts for the 
city, converted his touring into acts of reading and, through the retracing of fictional steps, his reading (of city and text) back into acts of touring.

The people I met understood their interpretive activity as a form of textual play, largely drawn from skills learnt whilst reading literature. ${ }^{10}$ They highlighted the qualities shared between city and text, in particular their belief that both relied upon the power of detail to awaken unseen contexts and thus release the imagination of the reader. I was told that the 'wonderful, tiny little details' found in the physical landscape of London matched those found in its literature, and vice versa. Severs' artwork attracted and inspired them precisely because it drew attention to this comparison. The room at the top of his house recalled the stories of Dickens, and by extension the atmosphere of Victorian London, simply by the careful arrangement of a few selected objects-a crutch, dirty sheets, a four poster bed, cobwebs, a work bench. Similarly, the passage from the novel by Ackroyd was persuasive, convincing readers that the strange house must exist because of the minute description of objects provided - the door, fanlight, the yellow brickwork, the mouldings, the stonework. The existence of detail, whether found in city or text, was believed to be the key to any successful reading. ${ }^{11}$

This appreciation of the level of detail in literature was said to highlight a further aspect of the category. As readers, they recognised that their attention was being drawn to blanks or absences. Detail, I was told, was just the 'tip of the iceberg'; it marked a gap, suggested something below the surface. Just as the words of a novel were significant for what they didn't say, so a physical detail in the city spoke of its omissions. This perspective is supported by a different theory of reading, one put forward by Iser (1980, 1992). He argues that the dynamism of literature is the result of its blank spaces (1992: 
55). Without these elements of indeterminacy, the absences that leave it up to the reader to draw together segments of narrative action and perspective, there would be no place for imaginative interventions. The act of establishing connections between textual segments, 'filling in the gaps left by the text itself' (55), is what reading is said to be about. A city of details (gaps) could be taken as read in the same way. Like a piece of literature, it was said to be capable of multiple realisations, animated by individual acts of attention to detail (filling in the gaps). In this case London was believed to provide the template for these imaginative interventions. Just like the text in reading, ${ }^{12}$ the city and its detail was thought to exercise ultimate control.

Rojek and Urry (1997: 14) point out that the commodification of memory at heritage sites and museums does not preclude individual acts of reminiscence. Visitors approach these centres in a number of different ways; they appropriate them in order to produce their own memories. In a similar way the people I knew approached objects in London and found new value in them. Attention to detail was said to provide a surfeit of memory, not only visions of the pasts and fictions of the city but at times what felt like personal recollections. It was believed that detail, by inviting them to fill in the gaps, sparked reminiscence and generated a sense and knowledge of those who went before. Their city was like a 'memory world' (Munn 1995: 87), ${ }^{13}$ it was thought to have the potential to activate the biographical and ancestral memory of its subjects. Objects such as fanlights, street names, door pediments or bollards could be treated as the marks of these ancestors 
(fictional or historical). They evoked the memory of enthusiasts, and in so doing made them feel part of the pasts and fictions they claimed to witness.

On a tour through 'Charles Dickens' London' I met Agnes. She was dressed in Victorian costume, with a crinoline skirt, jacket and bonnet, her faced puffed in white powder and thick rouge. Although the outfit was worn in order to please her customers, Agnes later told me that she found the clothes comfortable and preferable to modern fashions. She clearly knew the landscape of the author's imagination intimately. For her, those stories were still visible, animating the built environment around her. In subsequent conversations and private walks together, Agnes told me of her first encounters with the novels of Dickens. Although she only really got to know the city described by the author after she gave up her job as a drama teacher and took up guiding, her first contact with the stories was as a child. She remembered listening to radio readings from A Christmas Carol during the 1930s and being immediately struck by how cosy and familiar the story sounded. It reminded her of the anecdotes she heard her father tell about his childhood and of her own experiences of growing up in North London (at that time there were still gas-lit street lamps and horses among the motorised traffic). From that moment on, Agnes related, she felt strangely connected to the world portrayed in Dickens' novels. My mother used to say to me, 'I think you're mad!' But I say these people are friends, you know people like Charles Dickens have been a great influence on my life. I was an only child, I didn't have any friends, not at home, and I read, so the people in the books or the ones who wrote them were more real. 
Agnes expressed what felt like an emotional bond to the author and his characters, to the locations of their real or fictional lives. To her, the city described in these stories was highly personal, almost a memory.

Walking together through the district of Camden Town, Agnes told me of a curious discovery. Ever since first hearing A Christmas Carol on the radio, she had experienced strong feelings for the members of the Cratchit family and the Camden neighbourhood in which the novel was set. That affinity had recently received a strange twist when during a survey of her family history she had found that her own paternal grandfather was born in a street just one block behind the address given for the Cratchit family home. I was told that such entanglements, between Agnes, her ancestors and Dickens' characters, kept recurring. Weeks later, when walking together through Clerkenwell and Holborn, she pointed out Thavies Inn, the haunt of her very favourite character Mrs Jellyby of Bleak House. To her astonishment, she had discovered her ancestors had lived there too.

When I found out that my ancestor's family lived there I thought, 'Well, they must be mine!' Its another memory thing, a feeling that you have for a place, because I identified with the character in the book, and then you find you've got ancestors who actually lived on the spot. There is this feeling that you sometimes have, you know, 'Why do I like this? Why do I like this book? Is it the way I've been trained or is it something distinctive?' And then you find that there is some sort of link, that we have been here before. 
These landscapes, to which Agnes perceived herself returning, were said to be populated by people she 'knew' (either her ancestors or favourite literary characters). They appeared to surface in the present as at once her own and the city's memory.

Basso (1996: 76) states that among the Apache wisdom is seen as the outcome of deep reflection upon landscape. By observing different places, listening to stories about them and thinking of the ancestors who gave those stories voice, they gain knowledge about how to behave in the world (80). Indeed, the Apache landscape is viewed as a resource through which subjects can modify themselves or alter their thinking (85). To the enthusiasts for London I worked with, the city also revealed stories and memories, if one paid attention to it in the right way. The detail of places could release visions of pasts and fictions, the voice of their ancestors (these place-centred narratives, however, were not regarded as guides to situational problems). In doing so the city was said to merge with its visionaries, producing one subject with a single genealogy. By filling in the gaps or making detail appear to reveal kinship, these people seemed to make London slowly shed its differences. They perceived themselves knowing more and more about the city (and hence themselves). However, there was no comfort in the idea of an ultimate resolution. ${ }^{14}$ The thought that London might eventually complete itself, be tamed into some kind of primeval clarity, was disturbing to them. Agnes emphasised that she had no hope of ever fully recovering the city of her ancestors. Her project relied on the assumption that detail never gave up its capacity to shock and surprise. 


\section{Conclusion: limits}

For those I interviewed, there was a limit to their relationship to the city. The personality of London was believed to end in its suburbs. These were said to be areas of meaningless sprawl, of place without being. 'There is no pretension to anything', I was told, 'it's just a place. It's got some streets in it, it's got some houses. But it's got nothing there at all, no underpinning to it, no history to it that connects to anything else'. They complained that the suburbs had no pasts to solicit or draw out through detail; in living there one was forced to remain in the unremittingly visible and dreary present. This desire for depth, for engagement with the hidden layers of London, was often said to override practical concerns for comfort and security. Sally, for instance, perceived herself sacrificing the ease of suburban living for the stimulation of remaining in the inner city.

I mean you know even though I live in a kind of exceedingly grotty and ghastly bit of London, which is Hackney, there is an awful lot of history there. And I can just blot out the hideous bits of it and concentrate on that. Of course what I can do in Hackney is I can whisk myself back to the times of Pepys, when it was a lovely country area outside the City, where the air was fresh and people went to retire.

You know you can do that, just sort of think, 'Oh well, it wasn't always like this'.

Unlike the suburbs, she held that this district of London could reveal its past topographies in the present, thus open itself to her imagination. It was a place said to be animated by the person or being of London.

Eade (2000: 180) makes the point that the process of personifying a city, essentializing its characteristics, need not necessarily be conservative. He talks of radical personifications, those that challenge or resist dominant representations. Indeed, this 
particular form of reification (city as person) appears common to most understandings of London (4). It is important to acknowledge the critical edge of this analytical move. The apparent senility of London, a city that forgot immediate or recent experience in favour of its long-term memories, contrasted with the images of the city that enthusiasts resisted. Viewing London in this way allowed them to highlight the banality of commuter visions - of the city reduced to its utility as a network or transport hub. It also challenged those representations that threatened to limit the ways in which the built environment was presented and experienced - they did not describe a city of spectacle (Debord 1994) or a city of signs (Culler 1988). Their vision represented London as unstable and opaque, it was democratic in the sense that it did not necessarily fix which pasts could be seen where. Those who paid attention to detail claimed to experienced the city at a different pace (as someone born and brought up in South London I found their interpretive activity genuinely revelatory). They stopped in the street to look up or down while others rushed by, pausing to study objects that went unnoticed. They were not afraid to try new paths, to return and take time to sense a place or visit unexplored areas. To them, the city was there to be witnessed, continually re-discovered.

However, the act of personification also closes down understandings of the city. Eade warns that it can be a dangerous game (180), for it forgets there is never a single coherent definition of place (6); instead one always has a range of competing representations, each of which excludes at its limits. The assumption of a city full of details can obscure other radical visions, those that might rely on alternative interpretive strategies. In particular, it risks producing unwittingly racialized images of London. The preference for a metropolis that exists through its pasts rather than its present continually 
runs the danger of erasing recent immigrant histories. This representation of London can appear too self-contained, without reference to the links that have long joined the city to the larger world. Hackney, for instance, whose contemporary landscape Sally was so keen to 'blot out' is perhaps best known today for its large Afro-Caribbean and African populations. Rather than draw out their pasts from the detail around her, she chose to summon a seventeenth century country scene. When immigration histories were 'seen', they tended to be of more distant origin (the Huguenots or the Eastern European Jewish immigrants who came to the East End during the late nineteenth century). Any reference made to post-war immigrant communities usually reduced them to signs of exoticism (cf. Urry 1990: 144), of invigorating, yet alien difference. The districts of high minority population were explored but for the entry they were perceived to provide out of the city, into far-away lands. This view of London, as a city that contained pockets of the outside within itself, can be seen as the other side (the limit) of their claim to recognise a city of details. That representation risked turning large numbers of London's residents into displaced persons, people who implicitly did not belong.

While one might disparage this limited vision, it is important to remember that the reification of city as person remains a basic assumption of scholarly commentary (Eade 2000: 179). Recently, for example, London has been understood (and reduced) to the category of 'global city' (cf. Sassen 1991). This interpretation imagines the city as an entity that exists in its own right and has defining characteristic, but is also an abstract type (it shares that description with New York and Tokyo). Those scholars who look with such city-seeing-eyes tend to imagine that they analyse a place that exists prior to their interpretation. They present themselves as detached observers of urban life and fail to 
acknowledge that their description offers their own lived topography. At least the enthusiasts for London I met embraced the links between interpretive activity and a sensing of place. Although their representation had its own limits, its dimensions were more thoroughly explored. These people lived the city that they animated with the category of detail. 


\section{NOTES}

I wish to thank the people with whom I conducted fieldwork (pseudonyms are used in the text) for allowing me to attend their professional and personal tours and for agreeing to talk with me privately. I am grateful for the comments and criticisms of Tony Crook, Annelise Riles, Carol Greenhouse, Yael Navaro-Yashin, Shari Sabeti and Marilyn Strathern. I would also like to thank the editor and my reviewers for their thoughtful comments, which did much to shape the final form of this essay. Finally, my thanks goes to Clare College, Cambridge, and the University of Manchester for providing the financial support that made this research possible.

${ }^{1}$ In 1999 a series of bombs went off across London, targeted in areas of minority population. The first one exploded in Brixton, a strongly Afro-Caribbean area, the next one in Brick Lane in East London, a predominantly Bangladeshi area, and the last one, this time with fatalities, in a gay pub in the Soho area of the city centre. These events took place just before I started fieldwork.

${ }^{2}$ Fish (1980:13) is of course talking about interpretive communities within the discipline of literary criticism. The strategies that he identifies link sets of readers and constitute texts rather than cities, but I believe the principle is transferable. By paying attention to specific interpretive acts one can begin to appreciate the realities they shape and the subjects they constitute. Members of a single interpretive community are distinguished by what they agree to see (15).

${ }^{3}$ Strathern has her Melanesian subjects recognize the relation as an assumed form, something that exists $a$ priori, before the work of social action $(1988,1991)$; her English subjects identify the relation as the outcome of social action, an entity that joins individuals together (1992).

${ }^{4}$ Enthusiasts' vision of the city might also be opposed to the kind of 'Concept-city' described and critiqued by de Certeau (1988: 95). His example is New York; this is a city that he claims is often defined by the norms governing its arrangement, its grid, rather than its content. Such a depiction is said to leave the city forgetful, reducing its past and present to the status of hurdles that its future must overcome (de Certeau \& Giard 1998: 133).

${ }^{5}$ The image of enthusiasts as solitary visionaries of their own city could be compared to reported states of tourist experience. Cohen (1979: 190), for instance, describes what he terms an 'existential mode', in which 
people travel in order to achieve experiences of re-creation or conversion, a sense of 'switching worlds'. The traveller becomes attached to an elected location and simultaneously regards home as a state of exile. Urry (1995: 137-138) describes a 'romantic form' of tourist experience, which emphasizes solitude and privacy, providing a 'semi-spiritual' relationship to place. But the people I knew did not depict themselves as travellers or regard themselves in a state of exile; instead of journeying away in order to achieve engagement with place, they remained at home. It was other residents of London, not themselves, who they regarded as living in exile and not in tune with the city.

${ }^{6}$ Severs died on the $27^{\text {th }}$ of December 1999, some months after I visited his house and artwork.

${ }^{7}$ The attitude of enthusiasts to objects might be compared to the methodology of Benjamin (1979). Before starting his Arcades Project, he produced a number of literary or journalistic travel writings that attempted to depict the character of certain European cities. While he believed that no overarching perspective on them was possible, because of their fleeting and fragmentary nature, he still advocated the exercise of interpreting personality. Through reflection upon these cities' smallest objects, the arrangement of their spaces and buildings, he put forward what he called Denkbilder or 'thought-images', snapshots of urban character (Gilloch 1996: 38). Naples, for example, was said to be distinguished by its 'porosity' (Benjamin 1979: 169-171), by the frequency with which boundaries between old and new, sacred and profane, public and private seemed permeated. Moscow, by contrast, was said to be distinguished by the coexistence of these categories, the old juxtaposed next to the new but not merged with it (Benjamin 1979: 202-204; \& Gilloch 1996: 43).

${ }^{8}$ The idea that most of London's antiquity remains hidden contrasts with the attitude Faubion (1993) found among a group of Athenians. He argues that as residents of a city whose antiquity was said to remain obvious, these people felt compelled to articulate its present and future by always making something of its visible and monumental past (94). The Acropolis and Mount Likavittos, which are regarded as dominating the Athens skyline, provide a filter for the kind of experiences that its residents and visitors can have. ${ }^{9}$ Since Dickens, the common plot convention for any novel set in London is to name the districts and streets through which characters travel (cf. Moretti 1998). This writing strategy, the careful layering of stories onto the skeleton of a well known, named city, is said to leave the reader with an urban landscape that seems at once familiar and alien. 
${ }^{10}$ Rojek (1997: 54) provides another way of understanding these analytical moves — the process by which imaginary places come to have direct influence upon the perception of physical space. He talks of 'indexing' and 'dragging' activities that circulate around the viewing of objects in a built environment (in particular tourist sights). An index of representations, drawn consciously and unconsciously from multiple forms of media, is said to surround an object and constitute the basis for acts of framing (52). Rojek insists that the act of indexing does not prioritise between factual and fictional representations, but that they always exist in combination. Dragging is the process of individual selection, by which various elements are brought together in order to create new values for the object (54). Rojek presents this activity as a form of play, whose skills are not borrowed from reading literature, but from televisual and computer cultures and transferred into the consumption of place (71).

${ }^{11}$ Both Eco (1984) and Radway (1991) provide accounts of the textual strategy of detail. Eco argues that the reader's attention or involvement in a story is only achieved by first accurately presenting what is known and verifiable; descriptions of mundane detail are said to 'solicit our capacity for identification (1984: 167). Radway is struck by long passages in the genre of romance fiction devoted to the description of the material details of the world in which the story is set (most commonly, the style, colour and shape of women's fashions) (1991: 193). She claims that these descriptions of detail implicitly assert that the world of romance writing is as real and manifest as the world occupied by the reader (194).

${ }^{12}$ Although Iser $(1980,1992)$ attributes an active role to the reader in making meaning, he still assigns ultimate control to the text. Iser believes that the reader can choose how to fill in the gaps, but the structure or pattern of those blank spaces is dictated by the text.

${ }^{13}$ Munn (1995: 87) defines a 'memory world' as a template realized in verbal or visual form (her example is the Gisalo songs and dances of the Kaluli in Papua New Guinea) which is suited to social transaction. Like her account of Walbiri ancestral design (1973), these forms when realized are taken to have both generalized and particular effect; the memory world is at once a generalized sense of pastness and a specific biographical memory. In this regard, the songs are assigned similar qualities to the literary texts described by Iser $(1980,1992)$.

${ }^{14}$ The drive to resolve or enchain what appear discontinuous fragments of the city has its own literary tradition. It if often said, for instance, that Our Mutual Friend is the first novel of the modern city (cf. 
Donald 1999, Moretti 1998, Williams 1973). Dickens creates a story with disconnected plots, disparate characters and locations. But the author cannot resist offering a resolution to all this fragmentation. The random, labyrinthine nature of the city is eventually made legible, bound together by the power of institutions such as the law, money or trade, and by the revelation of lost kinship and secret romances. 


\section{REFERENCES}

Ackroyd, P. 1994. The house of Doctor Dee. London: Penguin.

Basso, K. H. 1996. Wisdom sits in places: notes on a Western Apache landscape. In Senses of Place (eds)

S. Feld \& K. H. Basso, 53-90.. Santa Fe: School of American Research Press.

Benjamin, W. 1979. One-way street and other writings. London: Verso.

De Certeau, M. 1988. The practice of everyday life. Berkeley: University of California Press.

De Certeau, M. \& L. Giard. 1998. Ghosts in the city. In The practice of everyday life, volume 2: living and cooking (eds) M. de Certeau, L. Giard \& P. Mayol, 133-143. Minneapolis: University of Minnesota Press.

Cohen, E. 1979. A phenomenology of tourist experiences. Sociology 13, 179-201.

Culler, J. 1988. Framing the sign: criticism and its institutions. Oxford: Blackwell.

Debord, G. 1994. The society of the spectacle. New York: Zone Books.

Donald, J. 1999. Imagining the modern city. London: The Athlone Press.

Eade, J. 2000. Placing London: from imperial capital to global city. New York: Berghahn.

Eco, U. 1984. The role of the reader: explorations in the semiotics of texts. Bloomington: Indiana University Press.

Faubion, J. 1993. Modern Greek lessons: a primer in historical constructivism. Princeton: Princeton University Press.

Fish, S.1980. Is there a text in this class: the authority of interpretive communities. Cambridge, Massachusetts: Harvard University Press.

Gilloch, G. 1996. Myth and metropolis: Walter Benjamin and the city. Cambridge: Polity Press.

Horne, D. 1984. The great museum: the re-presentation of history. London: Pluto.

Iser, W. 1980. Interaction between text and reader. In The reader in the text: essays on audience and interpretation (eds) S. R. Suleiman \& I. Crosman, 106-119. Princeton: Princeton University Press. 
1992. The reading process: a phenomenological approach. In Reader-response criticism: from formalism to post-structuralism (ed) J. Tompkins, 50-69. Baltimore: The John Hopkins University Press.

Low, S. M. 1996. The anthropology of cities: imagining and theorising the city. Annual Review of Anthropology 25, 383-409.

Lukács, G. 1981. The historical novel. London: Penguin.

MacCannell, D.1976. The tourist: a new theory of the leisure class. London: Macmillan.

Moretti, F. 1998. Atlas of the European novel 1800-1900. London: Verso.

Munn, N. 1973. Walbiri iconography: graphic representation and cultural symbolism in a Central Australian society. Ithaca: Cornell University Press. 1995. An essay on the symbolic construction of memory in the Kaluli Gisalo. In Cosmos and society in Oceania (eds) D. de Coppet \& A. Iteanu, 83-104. Oxfod: Berg.

Porter, R. 1994. London: a social history. London: Hamish Hamilton.

Radway, J. 1991. Reading the Romance: women, patriarchy and popular literature. Chapel Hill: University of North Carolina Press.

Riles, A. 2000. The network inside out. Michigan: University of Michigan Press.

Rojek, C. 1997. Indexing, dragging and the social construction of tourist sights. In Touring cultures: transformations of travel and theory (eds) C. Rojek \& J. Urry, 52-74. London: Routledge.

Rojek, C. \& J. Urry. 1997. Transformations of travel and theory. In Touring Cultures: transformations of travel and theory (eds) C. Rojek \& J. Urry, 1-22. London: Routledge.

Sasson, S. 1991. The global city. Princeton: Princeton University Press.

Sennett, R. 1994. Flesh and stone: the body and the city in Western Civilization. London: Faber \& Faber.

Strathern, M. 1988. The gender of the gift. Berkeley: University of California Press.

1991. Partial connections. Savage, Md : Rowman \& Littlefield.

1992. After Nature: English kinship in the Late Twentieth Century. Cambridge: Cambridge University Press.

1995. The relation: issues in complexity and scale. Cambridge: Prickly Pear Press.

Urry, J. 1990. The tourist gaze: leisure and travel in contemporary societies. London: Sage. 
1995. Consuming places. London: Routledge.

Walsh, K. 1992. The representation of the past: museums and heritage in the post-modern world. London: Routledge.

Williams, R. 1973. The country and the city. London: Chatto \& Windus.

Department of Sociology, University of Surrey, Guildford GU2 7XH.

a.reed@surrey.ac.uk 


\footnotetext{
${ }^{1}$ In 1999 a series of bombs went off across London, targeted in areas of minority population. The first one exploded in Brixton, a strongly Afro-Caribbean area, the next one in Brick Lane in East London, a predominantly Bangladeshi area, and the last one, this time with fatalities, in a gay pub in the Soho area of the city centre. These events took place just before I started fieldwork.

${ }^{2}$ Fish (1980:13) is of course talking about interpretive communities within the discipline of literary criticism. The strategies that he identifies link sets of readers and constitute texts rather than cities, but I believe the principle is transferable. By paying attention to specific interpretive acts one can begin to appreciate the realities they shape and the subjects they constitute. Members of a single interpretive community are distinguished by what they agree to see (15).

${ }^{3}$ Strathern has her Melanesian subjects recognize the relation as an assumed form, something that exists $a$ priori, before the work of social action $(1988,1991)$; her English subjects identify the relation as the outcome of social action, an entity that joins individuals together (1992).

${ }^{4}$ Enthusiasts' vision of the city might also be opposed to the kind of 'Concept-city' described and critiqued by de Certeau (1988: 95). His example is New York; this is a city that he claims is often defined by the norms governing its arrangement, its grid, rather than its content. Such a depiction is said to leave the city forgetful, reducing its past and present to the status of hurdles that its future must overcome (de Certeau \& Giard 1998: 133).

${ }^{5}$ The image of enthusiasts as solitary visionaries of their own city could be compared to reported states of tourist experience. Cohen (1979: 190), for instance, describes what he terms an 'existential mode', in which people travel in order to achieve experiences of re-creation or conversion, a sense of 'switching worlds'. The traveller becomes attached to an elected location and simultaneously regards home as a state of exile. Urry (1995: 137-138) describes a 'romantic form' of tourist experience, which emphasizes solitude and privacy, providing a 'semi-spiritual' relationship to place. But the people I knew did not depict themselves as travellers or regard themselves in a state of exile; instead of journeying away in order to achieve engagement with place, they remained at home. It was other residents of London, not themselves, who they regarded as living in exile and not in tune with the city.

${ }^{6}$ Severs died on the $27^{\text {th }}$ of December 1999, some months after I visited his house and artwork.

${ }^{7}$ The attitude of enthusiasts to objects might be compared to the methodology of Benjamin (1979). Before starting his Arcades Project, he produced a number of literary or journalistic travel writings that attempted to depict the character of certain European cities. While he believed that no overarching perspective on them was possible, because of their fleeting and fragmentary nature, he still advocated the exercise of interpreting personality. Through reflection upon these cities' smallest objects, the arrangement of their spaces and buildings, he put forward what he called Denkbilder or 'thought-images', snapshots of urban character (Gilloch 1996: 38). Naples, for example, was said to be distinguished by its 'porosity' (Benjamin 1979: 169-171), by the frequency with which boundaries between old and new, sacred and profane, public and private seemed permeated. Moscow, by contrast, was said to be distinguished by the coexistence of these categories, the old juxtaposed next to the new but not merged with it (Benjamin 1979: 202-204; \& Gilloch 1996: 43).

${ }^{8}$ The idea that most of London's antiquity remains hidden contrasts with the attitude Faubion (1993) found among a group of Athenians. He argues that as residents of a city whose antiquity was said to remain obvious, these people felt compelled to articulate its present and future by always making something of its visible and monumental past (94). The Acropolis and Mount Likavittos, which are regarded as dominating the Athens skyline, provide a filter for the kind of experiences that its residents and visitors can have.

${ }^{9}$ Since Dickens, the common plot convention for any novel set in London is to name the districts and streets through which characters travel (cf. Moretti 1998). This writing strategy, the careful layering of stories onto the skeleton of a well known, named city, is said to leave the reader with an urban landscape that seems at once familiar and alien.

${ }^{10}$ Rojek (1997: 54) provides another way of understanding these analytical moves - the process by which imaginary places come to have direct influence upon the perception of physical space. He talks of 'indexing' and 'dragging' activities that circulate around the viewing of objects in a built environment (in
} 
particular tourist sights). An index of representations, drawn consciously and unconsciously from multiple forms of media, is said to surround an object and constitute the basis for acts of framing (52). Rojek insists that the act of indexing does not prioritise between factual and fictional representations, but that they always exist in combination. Dragging is the process of individual selection, by which various elements are brought together in order to create new values for the object (54). Rojek presents this activity as a form of play, whose skills are not borrowed from reading literature, but from televisual and computer cultures and transferred into the consumption of place (71).

${ }^{11}$ Both Eco (1984) and Radway (1991) provide accounts of the textual strategy of detail. Eco argues that the reader's attention or involvement in a story is only achieved by first accurately presenting what is known and verifiable; descriptions of mundane detail are said to 'solicit our capacity for identification (1984: 167). Radway is struck by long passages in the genre of romance fiction devoted to the description of the material details of the world in which the story is set (most commonly, the style, colour and shape of women's fashions) (1991: 193). She claims that these descriptions of detail implicitly assert that the world of romance writing is as real and manifest as the world occupied by the reader (194).

${ }^{12}$ Although Iser $(1980,1992)$ attributes an active role to the reader in making meaning, he still assigns ultimate control to the text. Iser believes that the reader can choose how to fill in the gaps, but the structure or pattern of those blank spaces is dictated by the text.

${ }^{13}$ Munn (1995: 87) defines a 'memory world' as a template realized in verbal or visual form (her example is the Gisalo songs and dances of the Kaluli in Papua New Guinea) which is suited to social transaction. Like her account of Walbiri ancestral design (1973), these forms when realized are taken to have both generalized and particular effect; the memory world is at once a generalized sense of pastness and a specific biographical memory. In this regard, the songs are assigned similar qualities to the literary texts described by Iser $(1980,1992)$.

${ }^{14}$ The drive to resolve or enchain what appear discontinuous fragments of the city has its own literary tradition. It if often said, for instance, that Our Mutual Friend is the first novel of the modern city (cf. Donald 1999, Moretti 1998, Williams 1973). Dickens creates a story with disconnected plots, disparate characters and locations. But the author cannot resist offering a resolution to all this fragmentation. The random, labyrinthine nature of the city is eventually made legible, bound together by the power of institutions such as the law, money or trade, and by the revelation of lost kinship and secret romances. 